How to Cite

Pathy, S. K. (2019). Training needs analysis for non-gazetted police personnel: an empirical study of commissionerate police in

odisha. International Journal of Business, Economics \& Management, 2(1), 18-30. https://doi.org/10.31295/ijbem.v2n1.63

\title{
Training Needs Analysis for Non-Gazetted Police Personnel: An Empirical Study of Commissionerate Police in Odisha
}

\author{
Susanta Kumar Pathy \\ Centurion University, Odisha, India \\ Email: susntapathy@gmail.com
}

\begin{abstract}
A Training Needs Analysis (TNA) is used to assess an organization's training needs. The root of the TNA is the gap analysis. This is an assessment of the gap between the KSA components that the people in the organization currently possess and the KSA that they require to meet the organization's objectives. The training needs assessment is best conducted up front before training solutions are budgeted, designed and delivered. Professional policing promotes the rule of law and can support economic growth and improve the lives of the poor by protecting them from crime. The police personnel has a vital role in a parliamentary democracy. The society perceives them as custodians of law and order and providing safety and security to all. This essentially involves continuous police-public interface. In India, the police are often perceived as corrupt, ineffective and brutal, stemming from a plethora of systemic, organizational and behavioral challenges. Officers themselves report feeling unsatisfied, overworked and neglected by the system. The recommendations of the National Police Commission (1977-81) have suggested several measures to improve the standard of policing; however, seldom have they been implemented by successive governments. In the present study, four objectives have been formulated. To achieve the objectives of this study, questionnaires have been administered and interviews have been carried out with the respondents in the Commissionerate Police. An elective method of descriptive survey and case study has been applied to elicit information. Statistical techniques like percentage and frequency analysis have been conducted on the quantitative survey and content analysis has been performed on the interview schedule pertaining to training needs analysis of Non-Gazetted police personnel. Moreover, it was found from the study that there has been a wide gap between what is required and what is acquired. Keywords---basic and in-service training, HRD intervention, O-T-P approach, performance analysis model, training needs analysis.
\end{abstract}

\section{Introduction}

A Training Needs Analysis (TNA) is used to assess an organization's training needs. The root of the TNA is the gap analysis. This is an assessment of the gap between the knowledge, skills, and attitudes that the people in the organization currently possess and the knowledge, skills and attitudes that they require to meet the organization's objectives. The training needs assessment is best conducted up front before training solutions are budgeted, designed and delivered (Pérez et al., 2018; Sawali, 2018; Bire et al., 2019).

Professional policing promotes the rule of law and can support economic growth and improve the lives of the poor by protecting them from crime. The police personnel has a vital role in a parliamentary democracy. The society perceives them as custodians of law and order and providing safety and security to all. This essentially involves continuous police-public interface. The ever-changing societal situation in terms of demography, increasing rate and complexity of crime particularly of an organized nature and also accompanied by violence, agitations, violent demonstrations, variety of political activities, left-wing terrorism, insurgency, militancy, enforcement of economic and social legislation, etc. have further added new dimensions to the responsibilities of police personnel. Of late, there has been growing realization that police personnel has been functioning with a variety of constraints and handicaps, reflecting in their performance, thus becoming a major concern for both central and state governments. In addition, there is a feeling that police performance has been falling short of public expectations, which is affecting the overall

ISSN 2632-9476

Received Jan 20, 2019 / Accepted Jun 18, 2019 / Published Jul 05, 2019 
image of the police in the country. With a view to making the police personnel more effective and efficient especially with reference to their professionalism and public interface, several initiatives have been launched from time to time.

In India, the police are often perceived as corrupt, ineffective and brutal, stemming from a plethora of systemic, organizational and behavioral challenges. Officers themselves report feeling unsatisfied, overworked and neglected by the system. They often lack the adequate resources, skills, and aptitude of modern policing necessary to effectively perform their duties, yet police reform is rarely prioritized. The recommendations of the National Police Commission (1977-81) have suggested several measures to improve the standard of policing; however, seldom have they been implemented by successive governments (Loor et al., 2019; Hidayat et al., 2018; Estevez et al., 2018).

The significance and value of training have long been recognized. Given today's business climate and the exponential growth in technology with its effect on the economy and society at large, the need for training is more pronounced than ever (McClelland, 2002).

Therefore, organizations need to consider some important issues as they face the future: continuous technological change; the increasing removal of trade barriers; the consequent globalization; the volatility of customer demand within existing markets (Luoma, 2000; Ulrich, 2007). These continuous changes have challenged organizations to learn how to manage their businesses in the context of these continuous unpredictable changes, to learn how to confront these changes quickly and successfully. It is argued that, in order for an organization to achieve its objectives and goals, it needs to consider the important role of its people; it needs a highly competent, skilled and trained workforce.

The need to compete from the inside out has made organizations aim to increase the power of their people-related processes to build and sustain competitive advantage as the ultimate organizational objective; thus, outperforming competitors (Luoma, 2000).

\section{What is Training Needs Analysis?}

One of the clearest explanation of needs assessment is given by Anderson (2000), who writes that the needs assessment is the starting point in the training process. It is the phase in which an organization's needs are identified, forming the foundation of an effective training effort. Therefore, Training needs assessment is an ongoing process of gathering data to determine what training needs exist so that training can be developed to help the organization accomplish its objectives (Brown, 2002). Furthermore, the idea behind training needs analysis is that only when there is a match between training needs and the content of training, beneficial outcomes to organizational performance can be realized (Van Eerde et al., 2008).

Training Needs Analysis (TNA) is a fundamental part of the training system because it determines what training needs to be done so that money, time and effort are not wasted on unnecessary training activities. Tovey (2007), defines the TNA as "a systematic and thorough investigation of a problem with the purpose of identifying exactly the dimensions of that problem and whether or not it can be solved by training".

Training is responsible for building skilled, qualified and capable people, which helps organizations to improve their performance and adapt to any new change. This is why some successful organizations spend a great deal on the Training and Development function; however, organizations often train more employees than necessary, or the training investment is "wasted" on the wrong employees. Therefore, scholars generally recognized that the first important phase in planning and developing a training program is to determine the needs for such a program within an organization (Boydell, 2006).

\section{Identifying of Training Needs}

In general, identifying training needs step is recognized as one of the most important steps in training. This first step in the training process is primarily conducted to determine where training is needed, what needs to be taught, and who needs to be trained. Thus, without this step, there can be no solid prognosis to diagnose if the whole training process was correctly designed (Anderson, 2004; Bowman \& Wilson, 2008; Goldstein, 2003).

\section{Different TNA Models}

In general, training needs analysis models can be grouped into two major categories: the organization-task-person analysis framework (referred to as the McGehee and Thayer's three-level 'O-T-P' model in this research) and Mager, and Pipe's "Performance Analysis Model". The former is more popular among academicians, and many models developed by them are based on this foundation. The latter is popular among practitioners, and gaps between expected and current performance are considered as needs for training. 
Furthermore, these two theoretical models of TNA have dominated the training literature for over three decades. Within the O-T-P model, in particular, decisions being determined as a result of integrating macro through to microanalyses, arising from an investigation of training needs to meet organizational needs, task or job needs, through to the particular needs of the individual or person. By contrast, the performance analysis model focuses on identifying the areas of discrepancy between desired and actual performance and subsequently analyzing the causes of such discrepancies. Also, compared to the performance analysis approach, the O-T-P approach tends to be more strategic to organizational missions and needs for the future are also analyzed as part of the analysis (Taylor et al., 2008).

This study used the McGehee and Thayer's three-level (Organisation-Task-Person) conception of needs assessment because it is considered the core framework for needs assessment in the academic literature and most of the models developed since have been based on this three-level framework (Holton et al., 2000). Clarke (2003), also stated that the (O-T-P) model integrated macro through to microanalysis, arising from an investigation of training needs to meet organizational needs, task or job needs, through to the particular needs of the individual or person.

\section{The rationale of the study}

The rationale of this study comes from the increasing interest of academicians in training needs analysis to improve the performance of human resources for achieving the desired level of effectiveness and to remain successful. The review of the relevant literature on training needs assessment shows a real need for this study. The survey of the existing materials indicates that police training needs assessment in India has not been a widely researched area, more so, the training needs analysis of the non-gazetted ranks, which has received only transient attention from scholars working in the field.

The books and articles on training have been mainly written by serving and retired officials of the police, the subject has somehow not been able to hold the interest of academically inclined people outside the police profession. There is hardly any data available on police training needs analysis in Commissionerate Police, policing in the urban and the characteristic features of the city.

Though some material on police training has been brought out after the publication of the Report of the Committee on Police Training, it is only in the latter half of the 1980s one come across some useful literature on police training in India as well as in other countries. There is plenty of material although on the concept of Training, training procedures and appraisal mechanism in general but not much research has gone into training needs analysis and their applicability to police procedures. Police training needs analysis has so far been a neglected area of research study since no study has been conducted on the training needs analysis of non-gazetted police officers under Commissionerate Police in Odisha particularly after its establishment and become operational on 01.01.2008.

Hence a comprehensive study on the training needs analysis of non-gazetted police personnel is justified to bridge the gaps.

\section{Research Questions}

The researcher has formulated the following research questions which have been addressed through the study

Q1. What are the existing methods of training needs analysis of Commissionerate Police?

Q2. What is the strategic direction to do training needs analysis?

Q3. What are the emerging challenges in doing training needs analysis?

Q4. What are the main factors to determine an effective training needs analysis?

Q5. What are the technological barriers of TNA?

Q6. Are there any ideological barriers of TNA?

\section{Aim and Objectives of the study}

The aim of this research study is to examine the management of training needs analysis in order to identify the different barriers of doing an effective TNA process. Therefore, this study is specifically concerned with achieving the following research objectives:

1. To explore the nature of existing training needs analysis offered by Commissionerate Police.

2. To identify the challenges of training needs analysis.

3. To identify the main factors in order to determine effective training needs analysis.

4. To identify the barriers both technological in doing an effective training needs analysis. 


\section{Scope of the Study}

The Odisha Urban Police Act, 2003 (Odisha Act 8 of 2007) was enacted by the Legislature of the State of Odisha in the Fifty-fourth Year of the Republic of India and was assented to by the President on the 24th September 2007 to provide reorganization and regulation of police in certain Urban Areas of the State. The Commissionerate came into effect from 1-1-2008.

Then the need for the introduction of the system in the State of Odisha, especially the twin cities of Cuttack and Bhubaneswar has been assumed significance due to distinct features of the twin city.

The focus of study on Bhubaneswar has been influenced by the capital status of the city (being the capital of Odisha) and Cuttack a thousand years old millennium city, which not only defines the parameters of police work but entails a peculiar political and economic power structure sufficient to put unwieldy demands on police functioning. Bhubaneswar-Cuttack always has been strategic from a policing point of view.

Bhubaneswar is the capital city of Odisha having a rich cultural and architectural heritage. It is a tourist center as it has Hindu, Buddhist and Jain shrines and becomes the main contact point for the Golden Triangle including Konark and Puri. It is emerging as a first growing trade and commerce center, besides being the Headquarters of many Public and Private sector industrial houses. It is gaining prominence as an IT and Knowledge hub because of its infrastructural facilities and Rail, Road and Air connectivity.

Similarly, Cuttack is the former Capital city of Odisha and is almost a thousand years old. It is located at a distance of 28 kilometers from Bhubaneswar. Being surrounded by two rivers namely Mahanadi and Kathajodi, the city is known for being a trade center, educational hub and for its rich arts and cultural heritage. It has industries under the Choudwar and jagatpur areas. It has religious shrines of different faiths and known for various festivities. It has many research institutes of National repute. It has well-developed sports facilities and has good rail and road connectivity.

The scope of this study is limited to identifying the training needs of commissionerate Police. Thus various officials from top to bottom, policymakers, academics and experts in this area are included within the scope of the study. The scope of the study further extended to suggest recommendations for the policymakers and all to implement the training needs analysis models in identifying training needs of Commissionerate Police.

\section{Methodology}

The present study adopts an eclectic method combining the case study and the descriptive survey method of research. While adopting the descriptive method of research, both quantitative and qualitative approaches to data analysis have been followed. As the study is confined to the Commissioner of Police in Bhubaneswar-Cuttack twin city, it resorts to the case study method. For eliciting opinions and collecting descriptive data, survey method has been used. The tools were prepared and then validated after consulting with respondents who are not included in the sample (conducting pilot study) and with experts for monitoring language difficulty, clarification of terminology, overlapping of dimensions and of course modifying the no. of items in each tool as per requirement.

\section{Population and Sample of the study}

Three institutions namely; Biju Patnaik State Police Academy (BPSPA), Bhubaneswar; Police Training College (PTC), Angul; and Urban Police and Traffic Training Institute (UP \& TTI), Bhubaneswar are covered in this study. A number of trainees attended training during Jan. 2008 -July 2012 were 6560 which are considered as population and out of which 350 respondents who willingly provided their opinion are taken as sample and the sample-population percentage is 5.3\%. Categorywise the samples include Recruit Non-Gazetted Police personnel (138), Trainers (35), In-service police personnel who put five or more years of service (117) and gazette police personnel (60) and their percentages are $4.49,10.14,3.89$ and 42.25 respectively.

\section{Tools used for data collection}

Following tools used for data collection

1) Questionnaire for the recruit Non-Gazetted police personnel

2) Questionnaire for the in-service personnel who have put five or more years of service

3) Questionnaire pertaining to the training needs analysis of Non-Gazetted Non-Gazetted Police Personnel by Gazetted police personnel (Special Unit Heads) 
4) Interview schedule for Gazetted police personnel

5) Interview schedule for the trainers

6) Interview schedule for the trainees undergoing basic and refresher courses

\section{Data Collection}

Both primary and secondary data has been collected and used in this study. As this study employs both qualitative and quantitative techniques the combination of interview for qualitative data collection and questionnaire for quantitative data collection was used to achieve the objectives and to answer the research questions of this study. The period of data collection spread over August-2012 to May-2013.

\section{Analysis and Interpretation of Data}

The data has been analyzed both quantitatively and qualitatively keeping the four objectives in focus.

\section{Training Need Projections made by the BPSPA}

The following two tables indicate the training need projections over the period 2010 to 2014 . Table - 1 depicts the projections on basic training needs. Table -2 presents the projections on Advanced/ specialized training needs. Compared with the capacity of all training institutes of the State i.e. 1500, the deficiency calculated by taking the average of five years projection of basic training needs comes to $3125-1500=1625$. Further, taking into account the capacity of all training institutes of the State i.e. 1500, the deficiency calculated on the average of five years projection of advanced/specialized training needs comes to $3732-1500=2232$.

Therefore, the capacity of the training institutes to handle the training need load of the Police personnel is dismally low. Now reflecting on the qualitative capacity of the training institutes in terms of trained trainers, training tools, and facilities much remain to be achieved. This is a serious lacuna.

The Training policy as formulated by BPSPA for the Commissionerate policy visualizes that every non-gazetted police officer (up to the level of Sub- Inspector of police) shall necessarily undergo training as per BPR\&D norms. The special units and sub-divisions of the Commissionerate police also are required to follow the basic policy approach to ensure systematic training of all their personnel. This is being attempted through raising operational and functional standards of the training centers and urging the person to come forward and participate in the measures for up gradation of their skills. The training policy is yet to envisage the integration of non-formal training with distance education.

Table 1

Projection of basic training needs during 2010-2014

\begin{tabular}{|c|c|c|c|c|c|c|c|c|c|}
\hline \multirow[t]{2}{*}{$\begin{array}{l}\text { Sl. } \\
\text { No. }\end{array}$} & \multirow[t]{2}{*}{ Rank } & \multirow{2}{*}{$\begin{array}{l}\text { No. of } \\
\text { vacancy as } \\
\text { on } 31.12 .09 \\
\text { backlog }\end{array}$} & \multicolumn{5}{|c|}{$\begin{array}{l}\text { Likely vacancy due to retirement and } \\
\text { promotion to higher rank/ recruitment for } \\
\text { training in the next five years }\end{array}$} & \multirow[t]{2}{*}{$\begin{array}{l}\text { Total to } \\
\text { be } \\
\text { trained }\end{array}$} & \multirow[t]{2}{*}{ Training Capacity } \\
\hline & & & 2010 & 2011 & 2012 & 2013 & 2014 & & \\
\hline 1 & $\begin{array}{l}\text { Deputy Superintendent } \\
\text { of Police }\end{array}$ & Nil & 10 & 10 & 10 & 10 & 10 & 50 & \multirow{5}{*}{$\begin{array}{l}\text { Officers will be } \\
\text { trained at BPSPA, } \\
\text { Training } \\
\text { capacity-300 }\end{array}$} \\
\hline 2 & Sub- Inspector & 640 & 100 & 100 & 100 & 1000 & 100 & 1140 & \\
\hline 3 & Deputy Subedar & 332 & 20 & 20 & 20 & 20 & 20 & 432 & \\
\hline 4 & Sergeant & 41 & 5 & 5 & & 5 & 5 & 66 & \\
\hline 5 & Assistant Sub-Inspector & $205+1500$ & 150 & 150 & 150 & 150 & 150 & 2455 & \\
\hline 6 & Constable (civil) & 1475 & 700 & 700 & 700 & 700 & 700 & 4975 & \multirow{5}{*}{$\begin{array}{l}\text { Training capacity } \\
\text { PTC-500, } \\
\text { PTS-250, } \\
\text { APTC, } \\
\text { Jsg.-300 } \\
\text { UP\&TTI-150 }\end{array}$} \\
\hline 7 & Sepoy & 1985 & 350 & 350 & 350 & 350 & 350 & 3735 & \\
\hline 8 & $\begin{array}{l}\text { Constables of Indian } \\
\text { Reserve Battalion }\end{array}$ & 1391 & 122 & 122 & 122 & 122 & 122 & 2001 & \\
\hline \multirow[t]{2}{*}{9} & Assistant Driver & 151 & 50 & 50 & 50 & 50 & 50 & 401 & \\
\hline & & & \multicolumn{5}{|c|}{$\begin{array}{r}\text { Cumulative Total } \\
\text { Average Training Need }\end{array}$} & $\begin{array}{c}15625 \\
3125\end{array}$ & \\
\hline
\end{tabular}

Source: BPSPA, Bhubaneswar 
Table 2

Projection on advanced/specialized training needs

For the period 2010-2014

\begin{tabular}{lc}
\hline \multicolumn{1}{c}{ Types of Training } & Numbers needed \\
\hline Arms \& Explosives Tactics (AET) Training & 16,050 \\
Commando Training & 670 \\
Explosive Handling & 800 \\
Very Important Person(VIP) Security & 125 \\
.Craft of intelligence Training & 1,000 \\
Investigation of extremist/terrorist officer & 25 \\
Total & 18,670 \\
\hline
\end{tabular}

Source: BPSPA, Bhubaneswar

From the Table $3 \& 4$, it is found that, on questions pertaining to common areas like controlling of crimes, traffic control, and behavior of police towards the public, human rights there is a discernible difference between the opinions of recruiters and in-service trainees. Uncommon areas like the application of arms and ammunition, police Acts and judicial system, economic crime, cybercrime and community policing which are mainly for in-service personnel evoke different responses thereby indicating different role profiles.

Table 3

Areas on which the police must concentrate the most

(Responded by recruits)

\begin{tabular}{lllll}
\hline \multirow{2}{*}{ Areas } & \multicolumn{3}{c}{ Percentage } \\
(i) Law \& order and control of crimes & BPSPA & UP\&TTI & PTC & Total (Avg.) \\
$\begin{array}{l}\text { (ii) Cooperative behavior with people, particularly } \\
\quad\end{array}$ & 40 & 38 & 44 & 44 \\
with downtrodden & & 32 & 24 & 32 \\
$\begin{array}{l}\text { (iii) Traffic Control and pollution related problems } \\
\text { (iv) Control of crowds, rallies , mob with care and }\end{array}$ & 04 & 03 & 06 & 04 \\
$\quad$ patience & & 04 & 05 & 04 \\
(v) Others (Human Rights, VIP Security/all areas & 03 & 24 & 21 & 16 \\
$\quad$ Total & 100 & 100 & 100 & 100 \\
\hline
\end{tabular}

Source: Analysis of Collected Data

Table 4

Areas of policing in which the training is more required

(Responded by in-service personnel)

\begin{tabular}{lc}
\hline \multicolumn{1}{c}{ Areas } & Percentage \\
\hline i. Controlling of crimes and application of arms \& ammunition & 25 \\
ii. Police Acts and judicial system & 35 \\
iii. Human Rights \& behavior of police towards public & 08 \\
iv. Traffic control \& pollution related problems & 04 \\
v. Any other area (economic offense, cybercrime, community policing, & 28 \\
\multicolumn{2}{c}{ new acts) } \\
$\quad$ Total & 100 \\
\hline
\end{tabular}

Source: Analysis of Collected Data 


\section{KSA Required}

The following list illustrates the KSA required for effective police functioning which was collected from Gazetted Police Personnel and Trainers. After identifying the KSA set required for police functioning, they have also suggested the courses to be offered.

\section{Knowledge Inputs}

1. Indian Constitution, Law and Legal Enactments

a) Salient features of Constitution of India, Fundamental Rights, Directive Principles of State policy and Fundamental Duties

b) Indian Penal Code, Criminal Procedure Code, Indian Evidence Act

c) Police Ac(1861) and Local Laws

d) Minor acts pertaining to Social Legislation and Economic Offences

2. Socio-Economic and Political Structure

a) Indian Freedom Movement and National Traditions

b) Working of Parliamentary Democracy

c) Relationship Between Police and Political Representatives

d) Nature of Terrorism and Insurgency

e) Complexion of Social Problems Afflicting the Society

f) Impact of Globalization on Indian Economy

g) Role of Political Parties, Pressure Groups, Voluntary Agencies and Trade Unions

h) Psychology of Minority Groups, Communal Elements and Casteist Forces

i) Decentralization Process: Role of Panchayat Raj Institutions and Nagar Palika

j) Relationship of police with Quasi-police and Non-police Agencies

3. Crime Trends

a) Nature and Pattern of Crime

b) Individual and Collective Deviance

c) Crime Against Women, children and other Weaker Sections

d) Forensic science, forensic Medicine and Criminal Etiology

e) Theories of Penology: Typology of Penalties

f) Victimology: Understanding the Trauma of Victims

g) Medical Jurisprudence

h) Psychology of Criminals: Correction, Reformation and Recidivism

i) Emerging Crime Problems: Economic Crime, Computer-related Crime and Trans-national crime etc.

4. Police Procedures

a) Collection of Intelligence

b) Patrolling and Surveillance

c) Crime Investigation and Interrogation

d) Registration of Complaints

e) Preparation of Reports

f) Records Maintenance, Statistics and House-keeping

g) Court Procedures

5. Traffic Laws and Rules

a) Coordination and management of Traffic

b) Registration of vehicles

c) Traffic Engineering: Road Design, Infrastructure and Planning

d) Fist Aid to Accident Victims

e) Environmental Pollution and Related Acts

6. Science and Technology

a) Use of Computer and Electronics for Maintenance of Crime and other police-related Records

b) Operation of Modern Communication Equipment

c) Use of Polygraph or Lie Detector

d) Scientific and Technical Aids to Investigation

e) Use of Identity Kits and Photography 
7. Human Rights

a) Role of Ethics in Law Enforcement

b) Principles of Police Conduct: Good Manners and Etiquettes

c) United Nations Declaration on Human rights

d) Functions of International Human Rights Organizations

e) Constitutional Provision Regarding Human Rights

f) Image of Police and Police sub-culture

g) Role and functions of National Human Rights Commission National Commission for Women, National Minority Commission and National Commission for Schedule Castes and Schedule Tribes

8. Human Behaviour

a) Types of Human Behaviour: Legal and Societal Parameters

b) Nature of Individual and Group Behaviour

c) Psychopathic Behaviour and other Behavioural Aberrations

d) Crowd Behaviour and Mob Psychology

e) Police Behaviour with the Accused in Custody

f) Police Behaviour vis-à-vis Minorities, Women, Children, Old and Infirm

g) People's Expectations of the Police

9. Police Duties

a) Duties with Regard to Security and Escort

b) VIP Bandobast and Security Duties

c) Duties during fairs, Festivals and Rallies

d) Role during Natural Calamities Like Floods, Droughts, Fire and Earthquakes

e) Duties pertaining to Civil Aviation Security

10. Weapons and Explosives

a) Elementary knowledge of all types of Latest Weaponry

b) Use of Tear Gas and Water Cannons

c) Identification of Explosives

d) Bomb Detection and Diffusion

e) Map Reading

f) Counter-Terrorist Tactics

11. Police Organization

a) Police set-up at the Centre, State and District levels

b) Central Police Organizations

c) Police Auxiliary Agencies

d) Commissionerate system of Police

e) Characteristics Features of Urban Policing

12. Community Policing

a) Specific Community Policing Schemes Initiated by Delhi Police (a) Neighborhood Watch Scheme (b) Role of Special Police Officers(c) Beat Suraksha Samities (d) Crime Against Women Cell(e) Ready Reckoner Courtesy Contact Point System

b) Social Welfare Organizations run with the Assistance of Odisha Police

\section{Skill Inputs}

1. Conceptual and Cognitive

a) Observing and surveying the work in Hand: Probing into Critical Events

b) Appraising and Verifying Uncertain Circumstances: Using judgment and Sometimes Discretion to determine the Conflicting Nature of Happenings

c) Assimilating and Researching Information on people, places and facts: Updating on Every Type of Professional Competence Required and Unifying Disorganized Information

d) Understanding and Comprehending the data Available: Collating past and Present Information on Specific Issues

e) Analyzing and Assessing the Feasibility of Actions: Circumspection the Viability of Alternatives Available.

f) Decision-making and Planning on future of Action: Perceptively Formulating Work Maps

g) Supervising and Motivating the Subordinates: Providing Guidance and Leadership to Specific Tasks 
h) Monitoring and Evaluating the Nature of Tasks: Ensuring the Effectiveness of Procedures

2. Procedural and Functional

a) Putting knowledge into practice: Adhering to or Following Set Procedures

b) Organizing and Coordinating Activities: Administer Tasks Involving people and Events

c) Managing and Controlling Resources: Prioritizing Tasks in Order to Make Effective Use of Infrastructure

d) Probing and Investigating: Solving Cases of Crime and Violation of Law

e) Coping with variety of Tasks Simultaneously: Keeping Cognizance of Parameters of tasks

f) Record Keeping and Documenting: Ensuring Accuracy of Records

g) Applying technical Knowhow: Typing and operating computers

h) Handling of Weapons, Explosives and Scientific Aids

i) Driving, Arms cleaning and Providing Medical Aid

j) Recalling Detailed Information on people, places, and Facts from Memory

k) Making or understanding Portraits of the Absconding Accused

1) Stalking and Collecting Intelligence

m) Bomb-detecting and diffusing

n) Ambushing and De-ambushing

o) Map reading

3. Social and Communicative

a) Public Speaking: Being courteous and Tactful with Common people in Street

b) Expressing Views: Clear-cut and Concise Sharing of Information

c) Writing of Reports and Firs

d) Interpersonal Group Behavior: Working effectively as a team

e) Practicing self-control and Restraint in Trying Circumstances

f) Counseling and Mediating in Conflict Situations

g) Interviewing and interrogating the Suspects and Accused

h) Patient Listening: Being prepared to listen to the opinions of other

i) Recognizing Police Problems and Community Issues: Sharing of grievances after Duly Reflecting of Problems in Hand while Liaising with Non-Police organizations

j) Reporting clearly to the seniors: Assuming Responsibility for the Decision taken

\section{Attitude Inputs}

a) Approachable and Accessible: Being Cooperative with people who come in their Contact

b) Adjusting and Flexible: Being able to Adapt to new Procedure and Norms

c) Affirmative and Positive: Being Constructive in their Thoughts and Ideas

d) Committed and Dedicated: Possessing a Zeal to learn from Experience

e) Tolerant and Humane: Behaving Calmly with Complainants, Witness, Victims as well as the Accused

f) Empathetic and Sensitive: Identifying with other people's problems

g) Impartial and Just: Being able to Deal Objectively with Women, Children and Disadvantaged Sections of Society

h) Disciplined and Punctual: Being Able to exude a Sense of Timing even in frustrating Circumstances

i) Sociable and Affable: Displaying a Helpful Attitude and Responding to Others' Feeling and Ideas

j) Honest and Conscientious: Being Able to Recognize Mistakes and Accept Responsibility for them.

k) Reflective and Exploratory: Being Ready to Experiment with new Ideas

\section{Refresher Courses Needed At the Non-Gazetted Level}

1. Collection of Crime Intelligence

a) Typology of Crime: Crimogenic Factors and Consequences

b) Modus Operandi of criminals

c) Behavior and Psychology of Criminals

d) Understanding the Topography of Crime-infested Areas

e) Garnering Information on New Faces and Shady Elements

f) Day and Night Patrolling and Surveillance 
2. Community Policing

a) Working in a Group: Effectiveness of Inter-personal Behavior

b) Understanding Individual and Group Psychology

c) Role of counseling and Mediation

d) Public Speaking and Courtesy

e) Police Behavior vis-à-vis Minority Groups

f) Police Behavior vis-à-vis Women, Children and Disadvantaged Sections

3. Police Interaction with Non-police Agencies

a) Social, Economic and Political Context of Policing

b) Police and Social Welfare Agencies

c) Police and the Media

d) Relationship of Police and Political Representatives

e) Police and the Criminal Justice System

f) Interaction of Police with other Government Bodies

4. Court Procedures

a) Accusatorial System of Criminal Trials

b) Procedural Laws

c) Norms regarding admissibility of evidence

d) Presentation of Evidence

e) Investigation and Trial

f) Court Pairing and Escort Duties for the Constables and Head Constables

5. Problem-oriented Policing

a) Defining a Problem: Problem-analysis and problem-solving Approach to Issues Confronting the Police

b) Concentrated Attention on Trouble-prone Areas

c) Evaluating reports on tension area Surveys

d) Identifying Triggers

e) Drawing Plan of Action

f) Tension Control Measures

6. Sharing of Experiences

a) Different Policing Strategies and Behavioral Alternatives- Analyzing and Assessing Feasibility of Actions

b) Skill inculcation Capsules on Decision-making, Use of Discretion, Observing and Surveying, Analyzing and Evaluating

c) Familiarization with Behavioral Aberration

d) Personality Development-Cognitive and Emotional

e) Principles of Police Conduct-The dos and don'ts

7. Physical Fitness

a) Nature of Stressful Conditions

b) Different Types of Coping Skills

c) Role of Peer Counseling and Pep Talks

d) Exercises and Relaxation Techniques

e) Food and Hygiene

8. Crowd Control

a) Understanding Mob Psychology

b) Use of Rubber Bullets, Tear Gas, Water Cannons and other Public Weaponry

c) Use of cover: Weaponless defense and Mob Dispersal Operations

d) Exercise of Restraint and Discipline: Working through difficulties and Dilemmas

\section{Methods of Training Need Analysis}

The Tables 1and 2 provide overall futuristic training need projections. However, it is needed that TNA shall be a continuous exercise. As pointed out by the Gazette police personnel, there is an acute dearth of manpower in the police department. With ever-expanding role challenges cropping up, the Commissionerate is finding it imperative to prepare quickly the police personnel in multi-skill tasks.

Due to such an approach, the training centers are required to design short duration quick fix training programs to meet urgent contingencies. More than organizational long duration problems, operational short duration challenges 
become the basis of TNA. This is over above the traditional training in physical fitness, and such other routine job skills. Therefore, it can be inferred that formal TNA exercises at organizational level are almost conspicuous by their absence.

Referring to identifying the trainable police personnel, every new Recruited is subjected to a routine induction cum placement training. It is only for in-service police personnel that trainability becomes an issue for determination. In the absence of formal performance appraisal, identifying the training needs of individuals becomes a difficult task. It is the impressionistic judgment of the authorities on the trainability of individuals which might be becoming the decisive factor. Thus, it can be inferred that there are no formal systems in place in the Commissionerate of Police for TNA.

The Committee on Police Training (1973) observed that the effectiveness of training is determined by a combination of training needs analysis, training design, training delivery system and the organization to which the trainees will return. A training needs analysis stage thus comprises different stages and in order to evaluate training, dysfunctionalities have to be addressed at every stage. Each stage in training has been described as an amalgam of its varied constituents; thorough scrutiny of the interconnectivity of these variables and the numerous lacunae shredding them is a potent way of analyzing the dysfunctionalities in the training process and establishing the efficacy of training outcome. The training Needs analysis of Commissionerate police are grappling with various difficulties, which relate to the preparation of training syllabus, its systematic enforcement, appraisal and transfer to the job

\section{Objective-wise analysis and findings of the Study}

All the four objectives mentioned in the study have been qualitatively and quantitatively analyzed. The findings are as follows:

a) While examining the ever-expanding role of the Police personnel in the current times, it has been observed that Police job cannot be confined to any strict contours of a traditional job description. Therefore, job analysis will be a difficult proposition. The modern concept of 'boundary fewer jobs' becomes most applicable to the police functioning.

b) This changing nature of police job makes only need analysis difficult. But, the organizational analysis, identifying those problems which can be satisfied by the training intervention, even in the changing context becomes more essential. This aspect is conspicuous by its absence. Rather, training is assuming a quick fix formula to develop multi skills to compensate for the acute manpower shortage.

c) The TNA at individual level requires a thorough matching of an individual's KSA profile with that of task profile and organizational needs. As organizational needs are not properly identified, the task and person analysis for the purpose of training become difficult. The traditional HR systems lacking performance appraisal, career planning, and merit-based promotion systems compound the existing problems of training getting integrated with the HRD systems in the police administration. Thus, the training needs analysis is ad hoc in nature.

d) The opinion survey results show that the trainees do not know about the organization's efforts in preparing the TNA. They were also not aware of the criterion based on which the in-service trainees were chosen for training. This subscribes to the finding that there is no institutional arrangement for TNA.

\section{Recommendations and Suggestions for Further Research}

The recommendations made by BPR\&D, the highest Institution in the Country to improve the training needs analysis for Police personnel are first considered. Summing them up with the global practices and the findings made in this study, the final suggestions are attempted.

The changing trends in today's society indicate the following major dimensions of change and challenges as regards the police organization:

a) The increased pace of urbanization and industrialization causing rise in white-collar and organized crime, economic changes and socio-political instability resulting in public protests, demonstrations, and mass violence.

b) Social disparities, anomalies, lawlessness, and permissiveness, leading to a higher rate of juvenile delinquency, alcoholism, and social disorder.

c) Acceleration of social mobility giving birth to new patterns of criminal acts, declining standards of morality and degeneration of ethical values. 
d) The proliferation of social legislation and increasing burden of social responsibilities of the police leading to a gradual decline in respect of law, rampant corruption, increasing materialism at all levels, increased police stress, and an aggressive approach among police officers themselves for the solution of their problems.

e) Heightened threats to both internal and external security.

f) Smuggling, espionage, subversive activity along the international borders, terrorism, and threat to national security and integrity.

g) Increasing traffic problems due to an increase in traffic of all kinds with very little or no corresponding increase in transport facilities.

In this context, the training needs are required to be set out to meet the ever growing challenges and analysis should be made keeping these factors as a basis point of focus. The global practices are much more demanding particularly to make police more professional and modernized the training should start with the formal education system in college and universities with sufficient knowledge of KSA as opinioned by the gazette police personnel during their interview. Further to validate the findings of the study in different settings, comparative study of training needs analysis of nongazetted police personnel of Commissionerate police in Odisha with other Commissionerate police can be attempted.

\section{Implications of the Study}

a) The study has a larger implication in formulating training needs analysis for non-gazetted police personnel under Commissionerate police as it emphasizes the trainee's view, gazette police personnel's opinion and training needs projection as made by BPSPA for the state of Odisha including Commissionerate Police.

b) The study provides basic inputs to formulate training needs analysis and BPR\&D recommendations for the nongazetted police personnel in the context of India.

\section{References}

Anderson, G. (1994). A proactive model for training needs analysis. Journal of European industrial training, 18(3), 23-28. https://doi.org/10.1108/03090599410056577

Bire, A. R., Sauw, H. M., \& Maria, -. (2019). The effect of financial literacy towards financial inclusion through financial training. International Journal of Social Sciences and Humanities, 3(1), 186-192. https://doi.org/10.29332/ijssh.v3n1.280

Bowman, J., \& Wilson, J. P. (2008). Different roles, different perspectives: perceptions about the purpose of training needs analysis. Industrial and Commercial Training, 40(1), 38-41. https://doi.org/10.1108/00197850810841639

Boydell, T. H. (1971). A Guide to the Identification of Training Needs.

Brown, J. (2002). Training needs assessment: A must for developing an effective training program. Public personnel management, 31(4), 569-578. https://doi.org/10.1177\%2F009102600203100412

Clarke, N. (2003). The politics of training needs analysis. Journal of Workplace Learning, 15(4), 141-153. https://doi.org/10.1108/13665620310474598

Estevez, AG, Roche, JRF, Espinosa, AHR, \& Rodríguez, DL (2018). Social skills training program to prevent alcohol in university students. International Journal of Health Sciences , 2 (3), 4354. https://doi.org/10.29332/ijhs.v2n3.216

Goldstein, I. L., \& Ford, K. J. (1993). Training in organizations: needs assessment, development, and evaluation. Pacific Grove, CA: Brooks.

Hidayat, R., \& Budiatma, J. (2018). Education and job training on employee performance. International Journal of Social Sciences and Humanities, 2(1), 171-181. https://doi.org/10.29332/ijssh.v2n1.140

Holton III, E. F., Bates, R. A., \& Naquin, S. S. (2000). Large-scale performance-driven training needs assessment: A case study. Public personnel management, 29(2), 249-268. https://doi.org/10.1177\%2F009102600002900207

Loor, Y. C., Zambrano, J. L. Ávila, Loor, M. D. C., Viteri, C. G. V., \& Gámez, M. R. (2019). Professional training incident in local development. International Journal of Social Sciences and Humanities, 3(2), 24-30. https://doi.org/10.29332/ijssh.v3n2.290

Luoma, M. (2000). Developing people for business success: capability-driven HRD in practice. Management Decision, 38(3), 145-153. https://doi.org/10.1108/EUM0000000005342

McClelland, S. D. (2002). A training needs assessment for the united way of Dunn County Wisconsin. 
Pérez, A. V., Gámez, M. R., Briones, V. F. V., Viteri, C. G. V., \& Molina, L. A. V. (2018). Sustainable development seen from environmental training in university linkage. International Journal of Life Sciences, 2(1), 12-20. https://doi.org/10.29332/ijls.v2n1.75

Sawali, L. (2018). Drills forehand training strategy on the stroke of forehand drive ability in tennis. International Journal of Physical Sciences and Engineering, 2(2), 11-20. https://doi.org/10.29332/ijpse.v2n2.133

Taylor, P. J., Driscoll, M. P. O., \& Binning, J. F. (1998). A new integrated framework for training needs analysis. Human Resource Management Journal, 8(2), 29-50. https://doi.org/10.1111/j.1748-8583.1998.tb00165.x

Tovey, M. (2007). Training in Australia, Sydney: Prentice Hall Australia

Ulrich, D. (1997). Human resources champions: The next agenda for adding value to hr-practices. Boston: Harvard Business School Press.(1997b). Measuring human resources: an overview of practice and a prescription for results. Human Resource Management, 36(3), 303-320.

Van Eerde, W., Simon Tang, K. C., \& Talbot, G. (2008). The mediating role of training utility in the relationship between training needs assessment and organizational effectiveness. The International Journal of Human Resource Management, 19(1), 63-73. https://doi.org/10.1080/09585190701763917 